Alf Rolin

Høgskolen i Østfold

\title{
Argumentasjon og interaksjon i muntlig eksamen
}

\section{Sammendrag}

Artikkelen presenterer en undersøkelse av muntlige eksamener i lcererutdanningen. Den tar opp argumentasjon i studenters eksamensbesvarelser og samhandlinger, interaksjoner mellom studenter og eksaminatorer under eksamen. Og den diskuterer om mengden av argumentasjon i studenters besvarelser kan henge sammen med ulike former for interaksjon mellom studenter og eksaminatorer, slik at argumentasjon blir fremmet av bestemte former for interaksjon. Tidligere har intervjuundersøkelser av studenters og eksaminatorers erfaringer med muntlig eksamen blitt brukt til å vurdere hva som fremmer argumentasjon. Undersøkelsen som ligger til grunn for denne artikkelen, har i stedet brukt lydopptak av muntlige eksamener for å kunne avdekke faktiske forekomster av argumentasjon og sammenhenger det skjer i, og lagt det til grunn for vurdering av hva som fremmer argumentasjon. Resultatet av undersøkelsen er at argumentasjon forekommer langt oftere enn ellers $i$ studentenes besvarelser i sammenhenger hvor eksaminator henviser til og følger opp noe av det studentene sier, og det tolkes som indikasjon på at interaksjon som kommer av slik opptreden hos eksaminator, bidrar til a fremme argumentasjon i studentenes eksamensbesvarelser.

\section{Introduksjon}

Avsluttende eksamener inneholder som regel spørsmål eller andre utfordringer som skal besvares av de som har gjennomført en utdanning. Med stigende utdanningsnivå øker kravene i eksamensoppgavene og forventningene til eksamensbesvarelsene. I lærerutdanning blir det forventet at eksamenskandidatene i svarene de gir, også skal kunne begrunne, argumentere for sine påstander. For at studentenes argumentasjonsevne skal kunne bli gjort til gjenstand for vurdering i forbindelse med avsluttende eksamen, må vurderingsformene som brukes, gi rom for argumentasjon. I tidligere forskning om vurdering i høyere utdanning har muntlig eksamen blitt fremstilt som en vurderingsform som gir rom for argumentasjon, og det har blitt fremsatt teorier om at muntlig eksamen har særtrekk som bidrar til å fremme argumentasjon. Denne artikkelen vil undersøke om en mulig faktor innenfor muntlig eksamen, en faktor som eksaminator kan velge å ta initiativ til, bidrar til å fremme argumentasjon. "Eksaminator" brukes her og i fortsettelsen som fellesbetegnelse for eksaminator og sensor. Artikkelen vil besvare spørsmålet om interaksjon 
som kommer av at eksaminator henviser til og følger opp en students utsagn underveis i eksaminasjonen, bidrar til å fremme argumentasjon i studentens eksamensbesvarelse. Svaret artikkelen konkluderer med, er basert på empirisk undersøkelse av et utvalg muntlige eksamener med en form som er mye brukt i lærerutdanning i Norge. Eksamensformen innebærer at én student blir eksaminert gjennom samtale med eksaminator uten at det i timen før eksamen er oppgitt noe tema eller utdelt noe materiale som lærerstudenten kan bruke til forberedelse.

\section{Argumentasjon i læreryrke og lærerutdanning}

Rammeplanen for praktisk-pedagogisk utdanning i Norge fra 2003 sier, med sitat fra "Lov om universiteter og høyskoler, Kapittel 10a Lærerutdanning § 54a: "Formål 1. Lærerutdanning skal gjennom undervisning, forskning og faglig utviklingsarbeid gi den faglige og pedagogiske kunnskap og praktiske opplæring som er nødvendig for planlegging, gjennomføring og vurdering av undervisning, opplæring og oppdragelse” (UFD, 2003: 4). Her signaliserer ordene "som er nødvendig” at nivået på utøvelsen av ferdighetene skal sees i sammenheng med behovet for utøvelsen av dem i yrket studentene blir kvalifisert for. Er det behov for å kunne argumentere i læreryrket, og har i så fall behovet for å argumentere gjennomgått noen forandring de senere årene? Svein Sjøberg, professor i naturfagenes didaktikk ved Institutt for lærerutdanning og skoleforskning ved Universitetet i Oslo, hevder at behovet for å kunne argumentere er aktuelt i læreryrket, og at behovet er større nå enn tidligere:

\footnotetext{
"Lærere må til daglig treffe en rekke valg knyttet til undervisningene i sine fag, og de må kunne begrunne disse valgene. Først og fremst overfor seg selv, men også overfor kolleger, og selvsagt overfor elevene og deres foreldre. De må kunne argumentere for fagets betydning, og de må kunne begrunne sine valg av innhold, vinkling og metode. ... Dagens unge blir omtalt som en 'forhandlingsgenerasjon'. De krever begrunnelser og argumenter for alle valg. ... For meg er dette selve nøkkelen til å fagdidaktikkens betydning. Fagdidaktikken skal øke lærernes kompetanse til å treffe og begrunne gode valg” (mine uthevelser) (Sjøberg, 2006: 80 f. ).
}

Kravet til å kunne argumentere, som Sjøberg her fremhever for lærere i skolen, er i samsvar med kravene som stilles til studenter i rammeplanen som har ligget til grunn for de praktisk-pedagogiske utdanningene ved norske høgskoler og universiteter siden 2003. Rammeplanen sier at den kvalifiserte læreren skal ha en allsidig kompetanse, og beskriver deretter flere delkompetanser som studentene skal tilegne seg gjennom studiet. En av dem er didaktisk kompetanse. Det dreier seg ifølge rammeplanen blant annet om å kunne "velge og grunngi (min uthevelse) læringsinnhold, arbeidsmåter, bruk av læremidler og vurderingsformer (UFD, 2003: 5). Rammeplanen sier videre at "gjennom studiet 
skal studentene utvikle ... didaktisk kompetanse, slik at de kan planlegge, begrunne (min uthevelse), gjennomføre og vurdere elevtilpasset opplæring i samsvar med aktuelle læreplaner og lovverk” (UFD, 2003: 12). Kravene om at lærerstudenter skal kunne grunngi, begrunne og dermed argumentere for sine valg og standpunkter i saker som hører til utdanningen de gjennomfører, indikerer at det er grunn til å forvente at lærerstudenter kan vise evne til argumentasjon under avsluttende eksamen i pedagogikk og fagdidaktikk, og at det er legitimt å spørre om en eksamensform som da brukes, er egnet til å få fram argumentasjon slik at det kan bli gjort til gjenstand for vurdering.

\section{Argumentasjon i muntlig eksamen}

Argumentasjon kan defineres bredt som resonnementer hvor det inngår minst to informasjoner hvorav den ene begrunner den andre (Jørgensen og Onsberg, 2008:11 f.). Den engelske filosofen Stephen Toulmin lanserte i 1958 i boken The uses of argument en argumentasjonsmodell som beskriver argumenters oppbygning. Modellen som siden har blitt brukt som redskap til å analysere argumentasjon i ulike sammenhenger, fremstiller både sentrale elementer i en argumentasjon og relasjonene mellom dem. Modellen har seks elementer, tre som ifølge Toulmin er faste bestanddeler i en argumentasjon, og tre som er frie i den forstand at de ofte kan være med, men ikke behøver å være med for å utforme en argumentasjon. De tre faste elementene i hans argumentasjonsmodell er "claim", "datum" og "warrent" som på norsk kan oversettes til "påstand", "belegg" og "hjemmel". Påstanden er overordnet element i den forstand at den skal rettferdiggjøres ved hjelp av de andre elementene. Belegget er en informasjon eller et grunnlag som blir fremstilt som direkte støtte for påstanden. Hjemmelen er et generelt synspunkt som kan forbinde belegget med påstanden. Det generelle synspunktet kan deles av den som begrunnet et utsagn og den som påstanden begrunnes overfor, og derved utgjøre en felles basis for å akseptere påstanden på grunnlag av belegget. Følgende eksempel fra argumentasjon om utdanning og eksamen, viser hva de tre faste elementene i Toulmins argumentasjonsmodell kan inneholde og hvordan de kan henge sammen: (Påstand:) Per stryker til eksamen fordi (Belegg:) han ikke har lest pensumlitteraturen ettersom (Hjemmel:) studenter som ikke leser lekser, stryker til eksamen (se for flere eksempler med bruk av alle elementene i modellen Jørgensen og Onsberg, 2008:17 f. og 27ff.).

I muntlige eksamener gir studentene svar som inneholder påstander, og svarene øker i verdi om studentene også viser evne til å underbygge påstandene med henvisninger til belegg for dem og eventuelt også med henvisninger til hjemler for at det er sammenheng mellom påstandene og beleggene. Beleggene og hjemlene demonstrerer at svarene ikke er løse tanker og påstander, men uttrykk for kunnskap som er basert på innsikt i sammenhenger med relevans for 
eksamenens innhold. Verdien av at studentene lærer å argumentere for sine oppfatninger, og dermed også betydningen av å avdekke om de kan det ved eksamen, blir fremhevet i forskning på høyere utdanning av John B. Biggs som har vært professor i pedagogikk blant annet ved universitetet i Newcastle. Han peker i en artikkel med tittelen "Assessing for quality in learning” (Biggs, 2001: 65 ff.) på en sammenheng mellom studenters læring og utdanningsinstitusjoners bruk av vurderingsformer, som består i at studenter først ser på vurderingsformene og hva de krever, og deretter arbeider for å lære å oppfylle kravene. Høyere utdanning bør ifølge Biggs bruke vurderingsformer som etterspør bestemte kvaliteter for derved å legge til rette for at studentene bestreber seg på å utvikle de samme kvalitetene. Blant kvaliteter som det er ønskelig at studentene utvikler gjennom utdanningsløpet, fremhever han dyp forståelse til forskjell fra overflatisk forståelse. Og han fremstiller aktiviteter som bidrar til å utvikle dyp forståelse, som dyp læring: ”Deep learning means using the highlevel, abstract cognitive processes that we want our students to develop. It includes explaining, arguing, reflecting ...” (Biggs, 2001: 65). Argumentasjon blir her fremstilt som en kognitiv virksomhet på avansert nivå. I tråd med denne fremstillingen plasserer Biggs også det å rettferdiggjøre, begrunne noe, som er en sentral aktivitet i argumentasjon, på et avansert nivå i utvikling av dyp forståelse: "The students can compare and contrast, analyze, explain causes, justify, relate, and apply. This is operating at the relational level" (Biggs, 2001: 68). "Relasjonelt nivå" er navn på et av nivåene i SOLO-taksonomien. "Structure of the Observed Learning Outcome", forkortet til SOLO, er et hjelpemiddel til vurdering av læringskvalitet, og en taksonomi (klassifisering, ordning) på fem nivåer. Den er utarbeidet av Biggs i samarbeid med Kevin F. Collis på grunnlag av analyse og klassifisering av flere hundre prestasjoner av ungdom i utdanningssammenheng, og gir en systematisk beskrivelse av hvordan prestasjonene kan vokse i kompleksitet og abstraksjonsnivå (Biggs og Collis, 1982). Studenter som i sin læring har nådd relasjonelt nivå, har utviklet forståelse av hvordan de enkelte elementene i et emne han eller hun har kunnskap om, bygger på og støttes av andre elementer. Slik forståelse er nært forbundet med ferdigheten til å rettferdiggjøre, begrunne noe, som i hovedsak går ut på å kunne vise at noe bygger på, støttes av noe annet. Argumentasjon i studenters prestasjoner blir derfor regnet som uttrykk for forståelse på relasjonelt nivå. Betegnelsen "dyp forståelse” brukes om forståelse på relasjonelt nivå, men ikke om tidligere nivåer i SOLO-taksonomien (Ramsden, 2003: 57; Hattie og Brown, 2004: 5 f.; Biggs og Tang, 2007: 77 f.).

Flere forskningsartikler om vurdering i høyere utdanning har bedømt muntlig eksamen som egnet redskap til å avklare om studenter har dyp forståelse, og begrunnet denne bedømmelsen med at eksamensformen gir studentene mulighet til å utdype, forklare og forsvare sine svar på ulike spørsmål (Remer, 1990: 35 f.; Kehm, 2001: 27 og Miller, 2002: 12). At muntlig eksamen gir mulighet til å vise dyp forståelse tilsier at det i eksamensformen ikke er noe som hindrer 
studentene i å demonstrere evne til å se relasjoner og argumentere ved å trekke slutninger og gi begrunnelser i sine svar, men det sier ikke noe mer som avklarer om det er noe ved muntlig eksamen som fremmer argumentasjon. Bidrag til nærmere avklaring av dette spørsmålet har i stedet kommet i nyere forskning på muntlig eksamen i høyere utdanning som har lagt mer vekt på ulike former for interaksjon mellom den som blir eksaminert og de som eksaminerer.

\section{Argumentasjon og interaksjon i muntlig eksamen}

Argumentasjon skjer i muntlig eksamen i en sosial kontekst, det finner sted i en samhandling mellom studenten på den ene siden og eksaminator på den andre. Muntlig eksamen er per definisjon eksamen med bruk av munnen som uttrykksmiddel, bruk av tale om uttrykksform. Dette blir markert i forskjellige navn som "oral test", "oral interview" og "oral examination" (Pearce og Lee, 2009: 120). Joughin har i forskning om muntlig eksamen utvidet den snevre definisjonen av muntlighet som bruk av munnen og det talte som uttrykksmidler ved å referere til en teori om muntlig språks psykodynamikk. Teorien, som er hentet fra Ong, går i korthet ut på at en som bruker muntlig språk ofte 1) knytter seg personlig til det som sies, 2) står nært og direkte overfor den det tales til, og 3) kjemper for å påvirke andre gjennom sin tale (Ong, 1982: 43 ff., 269; Joughin, 2008: 31 f. og 2009: 3). Etter denne forståelsen av muntlig språk står den som bruker det overfor andre i en psykodynamisk interaksjon hvor argumentasjon fungerer som redskap til å overbevise de andre om betydningen av og berettigelsen til påstander som fremsettes. Det blir mer overbevisende når studenter under muntlig eksamen går fra å bare fremsette påstander til å presentere påstandene og i tillegg begrunne dem, det vil si argumentere. De karakteristiske trekkene som tillegges muntlighet i Ongs teori om det muntlige språkets psykodynamikk, blir ifølge Joughin særlig fremtredende der studentene opplever at den muntlige eksaminasjonen krever at de samhandler energisk med de andre aktørene ved å argumentere for sine standpunkter (Joughin, 2009: 8).

Muntlig eksamen har for andre også et element av sosial interaksjon som følge av eksamensformens plassering av studentene direkte overfor, ansikt til ansikt med de andre aktørene. Denne nærheten er personlig utfordrende fordi studentenes usikkerhet, tvil og sviktende evne til å gi gode svar på noen av spørsmålene kommer umiddelbart til uttrykk. Studenter forutser ifølge Joughin at de i muntlig eksamen risikerer å dumme seg ut overfor mennesker de respekterer høyt, og de søker å unngå det ved å forberede seg bedre enn til eksamensformer med mindre sosial interaksjon. Forventninger om at de kan møte overraskende spørsmål som åpenbarer deres svakheter for andre, bidrar til økt anstrengelse for å utvikle dyp forståelse. Og antagelse av at de i eksamen 
også vil få behov for å kunne argumentere for sine påstander, bidrar til mer og grundigere læring i forberedelsesprosessen

(Joughin, 2009: 1 f., 2010: 6,11,13 og 2011: 3)

For det tredje er det i muntlig eksamen en bestiller-leverer-interaksjon mellom aktørene, hvor eksaminator er fast bestiller og studenten er fast leverandør. Denne interaksjonen skapes og opprettholdes så lenge spørsmålene uttrykker bestemte krav og svarene oppfyller kravene. Trafford og Leshem fremhever utspørrernes rolle og spørsmålenes betydning i muntlig eksamen. De hevder at spørsmålene konstituerer en agenda som kan bli bestemmende for vurderingen av resultatet. Spørsmålene viser hvilke saker utspørrerne betrakter som viktige, og uttrykker samtidig deres forventninger til studenten. Spørsmål etter kunnskap inviterer til beskrivelse av et kunnskapsinnhold, mens spørsmål etter begrunnelse inviterer til argumentasjon. Den siste typen spørsmål, som kalles generiske spørsmål, gir studenten mulighet til å vise om hun i sin tenkning kan bevege seg fra deskriptivt nivå til konseptuelt nivå (Trafford og Leshem, 2002b, s. 36, 39 og 42 f.), noe som tilsvarer bevegelse fra tredje til fjerde, dvs. fra multistrukturelt til relasjonelt nivå i SOLO-taksonomien, hvor det siste innebærer evne til argumentasjon (Biggs og Tang, 2007: $77 \mathrm{f..})$

En fjerde mulig form for interaksjon i muntlig eksamen er dialog som her forstås som samtale mellom parter som lytter til og responderer på hverandres utsagn. Denne bruken av dialog-begrepet er hentet fra Joughins fremstilling av interaksjon som en dimensjon i muntlig eksamen med variasjon fra liten til høy grad. Siste del av skalaen, interaksjon av høy grad, betegnes der som dialog (Joughin, 2008: 5 ff. og 2010: 10 ff.). Ved minst grad av interaksjon er eksamen preget av at studenten presenterer sine kunnskaper og ferdigheter mens eksaminator har få innspill. Ved større grad av interaksjon veksler det mellom spørsmål og svar. Ved størst grad av interaksjon er eksamen preget av konversasjon som involverer "reciprocal statements by examiner and student in which each such statement includes a response to that made by the other participant” (Joughin, 2008: 9). Det spesielle med slik konversasjon i forhold til det øvrige innholdet av spørsmål og svar i en muntlig eksamen, er gjensidigheten i samtalen som innebærer at både eksaminator på den ene siden og studenten på den andre siden eksplisitt responderer på den andre partens utsagn. Mens rollefordelingen ellers i eksamen er at eksaminator stiller stadig nye spørsmål som studenten har til oppgave å respondere på, går i denne formen for konversasjon også eksaminator inn i respondentrollen ved eksplisitt å vise studentens utsagn oppmerksomhet gjennom kommentarer, oppfordringer til utdyping eller andre former for oppfølging. Slike innspill som bryter rekken av stadig nye spørsmål, skaper bevegelse fra ensidig spørrende relasjon i retning av en diskursiv form for relasjon som åpner for samtale på ulike nivåer om faglige spørsmål (Trafford, 2003: 117).

Studenten utfordres til å prestere i muntlige eksamener også når interaksjon med eksaminator har dialogform. Trafford og Leshem deler inn i tre områder 
som studenten utfordres på: "explicit scholarship", "personal resilience” og "interpersonal awarenes" (Trafford og Leshem, 2002a: 9), som kan oversettes til "faglighet", "faglig og emosjonell utholdenhet" og "relasjonskompetanse" (Dobson, 2007: 147 og 2009: 195). Det andre av disse områdene omhandler evne til å holde følge med eksaminator når han inviterer til samhandling på et nivå, enten det er lavt eller høyere. Det gjelder om studenten har "confidence in ... relating answers to evidence and/or concepts in a way that engage with the examiners", og "a positive contribution to moving the discussion onwards and engaging with the examiners at any level of questioning" (Trafford og Leshem, 2002a: 9). Det er eksaminators innspill til samtalen som angir et nivå. Han kan for eksempel be studenten om å utdype et svar som er uten begrunnelse, og studenten kan oppfatte dette som en invitasjon til å forbedre svaret, og deretter høyne nivået på svaret ved å "relatere det til evidens", som er Traffords og Leshems uttrykk for slik argumentasjon

Fire mulige svar på spørsmålet om hva som fremmer argumentasjon i muntlig eksamen, kan utledes fra teoriene som er presentert ovenfor: 1 . en psykodymanisk interaksjon knyttet til bruk av muntlig språk kan få studenten til å ville påvirke og overbevise med bruk av argumentasjon som redskap; 2. en sosial interaksjon med risiko for å åpenbare svakhet direkte overfeor andre, kan få studenten til å sikre seg på forhånd ved å forberede både svar på mulig spørsmål og argumenter til å forsvare dem ved behov; 3. en bestiller-levererinteraksjon i muntlig eksamen kan få studenten til å gi begrunnelser eller annen form for argumentasjon ganske enkelt fordi det blir spurt etter det; 4. en dialoginteraksjon i form av samtale hvor både student og eksaminator responderer på hverandres utsagn, kan få studenten til å oppleve at de andres bidrag legger samtalen på et nivå som inviterer til argumentasjon.

\section{Undersøkelse, materiale og metode}

I det følgende vil jeg presentere en undersøkelse av argumentasjon i muntlige eksamener i høyere utdanning. Den registrerer faktiske forekomster av argumentasjon i studenters svar ved muntlige eksamener, og ser funnene av argumentasjon i lys av sammenhengene de står i, for så å vurdere om funnene kan tolkes som bekreftelse eller avkreftelse av følgende tese utledet fra det fjerde av svarene ovenfor: samtale i muntlig eksamen hvor både student og eksaminator responderer på hverandres utsagn, bidrar til å fremme argumentasjon i studentens svar.

Undersøkelsens materiale er lydopptak av åtte muntlige eksamener i pedagogikk og fagdidaktikk ved avslutningen av årsstudiet for praktiskpedagogisk utdanning ved Høgskolen i Østfold. De åtte eksamenene var et tilfeldig utvalg blant ca 50 eksamener. Både pedagogikk og fagdidaktikk var 
tema i hver eksamen. Studentene ble eksaminert enkeltvis gjennom samtale med eksaminator, og de fikk i timen før eksamen ikke oppgitt noe tema eller utdelt noen tekst de kunne bruke til forberedelse. De kunne ta med seg en utviklingsoppgave med et omfang på ca. 25 sider som de selv hadde skrevet om et emne innenfor pedagogikk og fagdidaktikk, og som tidligere hadde vært gjenstand for vurdering, men det var ikke separat presentasjon av denne eller noe annet i den muntlige eksamenen.

Eksamen i praktisk-pedagogisk utdanning ble valgt som gjenstand for undersøkelse av argumentasjon i muntlig eksamen fordi dette studiet i følge den nasjonale rammeplanen skal utvikle kompetanse i å argumentere for blant annet valg av læringsinnhold og arbeidsmåter, jfr. avsnittet ovenfor om læreryrke og lærerutdanning. Avsluttende eksamen ble valgt fordi studentene på det tidspunktet i studiet kan forventes å oppfylle kompetansekravene, og Høgskolen i Østfold ble valgt som eksamenssted fordi forventning om argumentasjon i eksamen der var særlig fremhevet i styringsdokumentene. Ved siden av at den lokale studieplanen for praktisk-pedagogisk utdanning gjenga den nasjonale rammeplanens krav om didaktisk kompetanse (HiØ, 2007), fikk alle involverte i eksamenene tilsendt et skriv fra studieledelsen med tittelen "Informasjon til studenter, sensorer og veiledere”, som i orienteringen om den avsluttende muntlige eksamenen sa at "samtalen skal få fram viktige sider ved hva den enkelte kandidat kan stå for som framtidig lærer, gjennom å begrunne og argumentere for viktige sider ved lærerprofesjonen, fagdidaktisk og pedagogisk" (HiØ, 2008).

Registreringen av argumentasjon ble avgrenset til en av de første og dermed mest sentrale operasjonene i Toulmins argumentasjonsteori, nærmere bestemt begrunnelse av påstander gjennom henvisning til et eller flere belegg. Den ble videre avgrenset til tekstkonstruksjoner hvor "fordi" eller "for" blir brukt som markører for begrunnelse. De to ordene ble valgt som markører fordi de ofte brukes i overganger mellom påstander og belegg (Jørgensen og Onsberg, 2008: 20). Mengden av argumenter som skulle undersøkes, ble i tillegg redusert ved at oppmerksomheten ble rettet mot påstander som omhandlet noe pedagogisk eller faglig, fordi bare disse var direkte relevante for den praktisk-pedagogiske utdanningen som eksamenene ble arrangert innenfor.

Registrering av samtale for vurdering av om det bidrar til å fremme argumentasjon, ble utført med redskap hentet fra Traffords, Joughins og Dobsons teorier om muntlig eksamen. Trafford pekte på at eksaminator kan gå ut av en rent spørrende relasjon og innlede samtale, diskusjon med studenten (Trafford, 2003: 117), og Joughin fremholdt som kjennetegn på samtale, dialog at eksaminator responderer på studentens utsagn i likhet med at studenten hele veien responderer på deres utsagn, slik at det skapes samtale med gjensidig respons.

Dobsons spesielle bidrag er bruk av begrepene "språkspill" og "konversasjon" til beskrivelse av muntlig eksamens innhold (Dobson, 2007: 140 
f.). Av språkspill som kan registreres, nevner han fire: 1. undersøkende, 2. evaluerende, 3. rapporterende, og 4. hilsende og avsluttende språkspill. Det første av disse utgjør største delen av eksamen, utvekslingen av spørsmål og svar, samtalen som skal avdekke studentens kunnskaper og ferdigheter. Konversasjon i muntlig eksamen fremstiller Dobson, med uttrykk hentet fra konversasjonsanalyse, som at deltakerne opptrer en etter en med innspill som vedlikeholder flyten i samtalene eller innleder og avslutter deler av samtalene. Det siste skjer både i overganger mellom språkspillene og innenfor de enkelte språkspillene som er beskrevet ovenfor. Det betyr at det for eksempel innenfor det undersøkende språkspillet, er flere mindre samtaleavsnitt med hver sine innledninger og avslutninger.

To typer avsnitt har jeg valgt å registrere der det i materialet forekommer argumentasjon i studentens svar. Første type er avsnitt som består av ordinær veksling mellom nye spørsmål fra eksaminator og svar fra studenten. Andre type avsnitt er samtaler med gjensidig respons som innledes ved at eksaminator avviker fra den ordinære vekslingen. Han henviser eksplisitt til noe av det studenten har sagt, i stedet for å gå direkte videre til nytt spørsmål. Henvisningen markerer at det er noe studenten kan fortsette på. Hva fortsettelsen skal bestå i, kan eksaminator bestemme nærmere gjennom oppfølgingsspørsmål eller forskjellige oppfordringer. Til registreringen av samtaleavsnitt med gjensidig respons har jeg valgt å bruke som markør henvisninger til studentens svar der slike henvisninger danner opptakt til oppfølgingsspørsmål eller til oppfordringer om videre utdyping eller begrunnelse. Slike samtaleavsnitt kan strekke seg over få eller mange gjensidige responser, men avsluttes når det igjen stilles nytt spørsmål uten henvisning til noe studenten har sagt.

Begge typer avsnitt er det eksaminator som tar initiativ til. De første ved å innlede med nye spørsmål, de andre ved å innlede med henvisning til noe studenten har uttalt og på den måten skape samtale med gjensidig respons. Registreringen av eksempler på argumentasjon i studenters svar i begge typer avsnitt blir utført med tanke på at det vil styrke tesen dersom det viser seg å være betydelig flere eksempler på argumentasjon hvor eksaminator bryter ut av rekken av stadig nye spørsmål og initierer samtaler med gjensidig respons. Og det vil svekke tesen tilsvarende dersom det viser seg å være betydelig færre eksempler på argumentasjon i studenters svar i avsnittene hvor eksaminator initierer samtaler med gjensidig respons.

Undersøkelsens materiale var opptak av muntlige eksamener. Studentene kunne som nevnt bringe med seg til de muntlige eksamenene en skriftlig oppgave som tidligere hadde vært gjenstand for vurdering, og både eksaminator og student kunne bringe noe fra den inn i den muntlige samtalen. For å skape mulighet for å vurdere argumentasjon i studentenes svar i muntlig eksamen som ikke har befatning med noe skriftlig arbeid, ble det også registrert hvilke avsnitt som berørte innholdet i den skriftlige oppgaven, og hvilke som ikke gjorde det. 


\section{Funn av argumentasjon og interaksjon}

I de åtte muntlige eksamenene som utgjorde materialet, ble det registrert 110 avsnitt med spørsmål fra eksaminator og påfølgende svar fra student med bruk av "for" og "fordi".

I 19 av de 110 avsnittene ble ordene «for» og «fordi» ikke brukt i sammenheng med argumentasjon i form av begrunnelse av påstander. Der ble "for" eller "fordi" brukt til noe annet, for eksempel til angivelse av årsaker til faktiske forhold, slik som at elever ikke fikk som oppgave å forbedre tekster etter tilbakemeldinger fra lærere fordi formativ vurdering ikke ble praktisert ved en skole. Eller det var tale om tilordninger der "for" ble brukt for eksempel til å uttrykke at et referat var skrevet for dokumentasjon av at arbeid var utført, eller at en ordning gjaldt for noen bestemt. Det var også ufullstendige setninger, som ikke er uvanlig i muntlig tale, hvor "for" eller "fordi" ble brukt uten at det fulgte noen begrunnelse for en påstand.

I 28 av de 110 avsnittene hvor «for» eller «fordi» ble brukt i sammenheng med begrunnelse, var det ikke tale noe faglig eller pedagogisk med relevans for den praktisk-pedagogiske utdanningen som eksamenene ble arrangert innenfor. Der var det i stedet for eksempel tale om lønnsnivået til kommuneansatte, om erfaringer og valg i egen tidligere utdanning, om egne familieforhold eller om rent organisatoriske forhold.

I de resterende 63 avsnittene ble det funnet argumentasjon hvor "for" eller "fordi" ble brukt som markør for belegg, begrunnelse, og hvor det samtidig var omtale av noe faglig eller pedagogiske med relevans for den praktiskpedagogiske utdanningen.

17 av de 63 avsnittene blir innledet av nye spørsmål fra eksaminator. Det vil si at de tar opp temaer som ikke er omtalt direkte av lærerstudenten på forhånd, og stiller spørsmål i tilknytning til dem. For eksempel: ”Du får en klasse og så skal du bruke ... Hvordan ville du gjort det da?" Det er mest bruk av spørreordene "hvordan" og "hva". Eksempler på bruken av det siste er "hva er ...", "hva slags ..." og "hva tenker du rundt det?" Bruken av disse spørreordene fungerer som oppfordringer til beskrivende redegjørelser. Det er også to avsnitt der "hvorfor" blir brukt til å be om begrunnelse. Lærerstudenten tillates å gi lange svar før eksaminator bryter inn med nytt spørsmål, og studentenes argumentasjon kommer ofte langt inne i svarene.

46 av de 63 avsnittene blir innledet av at eksaminator henviste til noe studenten hadde sagt, og kom med oppfølgingsspørsmål eller til oppfordringer om videre utdyping eller begrunnelse, for eksempel slik: "Da snakker du om vurdering, og så lurer jeg på ...”; ”Du har snakket mye om ... Hvilken rolle spiller den kunnskapen ...". Andre steder kommer tilknytningen til lærerstudentens svar til uttrykk i bruk av henvisende småord som for eksempel "det” eller "sånne: "Men hvorfor er det [du nevnte nå] spesielt viktig..."; ”Det er vanskelig ... i sånne tilfeller [som du nå beskrev]". Klammeparentesene er 
her mine tilføyelser for å synliggjøre småordenes funksjon i sammenhengen. Andre steder igjen består tilknytningen til lærerstudentenes tidligere utsagn i at eksaminator gjentar noe av lærerstudentens svar for så å følge opp med spørsmål for eksempel om hvilke utfordringer det innebærer.

Argumentasjonen $\mathrm{i}$ de 43 avsnittene kommer som regel tidlig i lærerstudentens svar, i mange tilfeller helt i starten av svaret som følge av at lærerstudenten slutter seg til en påstand i spørsmålet fra eksaminator og begrunner den. For eksempel der sensor spør: ”Fører den [elevsamtalen som lærerstudenten har omtalt tidligere] til noe som helst?”, og lærerstudenten svarer: ”Ja, det gjør den, fordi... da har jeg alltid de i tankene når jeg planlegger undervisningen”. Eller der eksaminator nevner betydningen av faglig dyktighet, og lærerstudenten kommenterer: "Så synes jeg også at den faglige dyktigheten er utrolig viktig, da. ... for det så jeg jo nå, på de gangene jeg ikke hadde fătt forberedt meg nok, så kom uroen”.

Følgende utdrag fra materialet viser mer utførlig en samtale hvor eksaminator henviser til noe studenten har sagt, hvor studenten argumenterer i sitt svar og hvor innholdet er faglig eller pedagogisk. Studentens utsagn er merket med”-” og eksaminators utsagn er merket med "*”.

”- Jeg har sett ... på aktivitetsorientert opplæring, det er hvordan vi skal aktivisere minoritetsspråklige elever som har dårlige kunnskaper, språkkunnskaper ... jeg ser det som veldig viktig å aktivisere elevene.

* Hvorfor synes du det er viktig med aktivitet ...

- Jeg har sett ... på Piagets teori også. ... han mener at barn tilegner seg kunnskaper etter å være aktive eller etter å handle. ... Og han ... ser prosjektarbeid som en viktig del av undervisningen.

* Men hvorfor er det spesielt viktig for minoritetsspråklige, synes du?

- Ikke bare for minoritetsspråklige, for elevene generelt. Men viktig for minoritetsspråklige også, for da får de en mulighet til å være en del av klassen. De får mulighet til å kommunisere mer, være aktive, vise fram hva de kan. Og hvis de ikke har så gode språklige kunnskaper, så blir de på en måte tatt vare på av den gruppen som skal opparbeide det prosjektet. De får hjelp og støtte gjennom samarbeidet.”

Dette utdraget viser en utvikling i lærerstudentens omtale av aktivitetsorientert opplæring. Det begynner med informasjon om at lærerstudenten har sett på emnet og om et standpunkt for påstanden om at det er viktig å aktivisere. Det fortsetter i det andre svaret med tilknyting til teori, og det slutter med nærmere bestemmelse av en form for aktivisering, med inndragning av de sosiale dimensjonene ved denne formen for aktivisering, og med en nyansert begrunnelse for den innledende påstanden om viktigheten av aktivisering med særlig henblikk på hvordan det kan møte flere av behovene til en bestemt elevgruppe. Eksaminators tilknytning til og oppfølging av lærerstudentens to første svar bidrar til utviklingen i besvarelsen. Det første svaret ville neppe blitt utviklet videre hvis eksaminator etter det hadde valgt å gå over til å spørre om noe annet. 
Funnene som er referert ovenfor, viser at det i materialet er flest eksempler på argumentasjon i studentenes svar i avsnitt hvor eksaminator henviser til studentens utsagn, og ved det tar initiativ til samtale hvor både student og eksaminator responderer på hverandres utsagn. Av 63 avnitt med argumentasjon i studentenes svar, er 17 innledet av nye spørsmål fra eksaminator, mens 46 er innledet av henvisning fra eksaminator til noe studenten har sagt, og oppfølging av det. I forhold til avsnitt med argumentasjon og innledning med nye spørsmål, er det dermed i materialet 2,7 ganger flere avsnitt med argumentasjon og innledning med henvisninger til noe studentene har sagt.

Blant avsnittene med argumentasjon i studentenes svar ble det også gjennomført en registrering av hvilke som berører innholdet i den skriftlige oppgaven studentene kunne ta med seg, og hvilke som ikke gjør det. Resultatet ble totalt 46 avsnitt som har argumentasjon i studentens svar, men ikke berører den skriftlige oppgaven. 11 av disse avsnittene er innledet av nye spørsmål fra eksaminator, mens 35 er innledet av henvisning fra eksaminator til noe studenten har sagt, og oppfølging av det. Det relative forholdet mellom antall avsnitt av begge typer blir her dermed 11 til 35, som vil si 3,2 ganger flere avsnitt med argumentasjon og innledning med henvisninger til noe studentene har sagt.

\section{Diskusjon}

Hovedfunnet i materialet er at det er mest argumentasjon i studentenes svar i muntlige eksamener der eksaminator henviser til og følger opp studentens utsagn. Dette funnet styrker tesen om at samtale i muntlig eksamen hvor både student og eksaminator responderer på hverandres utsagn, bidrar til å fremme argumentasjon i studentens svar. Samtalen det her er tale om, har ovenfor blitt beskrevet nærmere i tilknytning til Joughins teori som samtale med dialoginteraksjon. Og hva det kan være i eksaminators invitasjon til slik samtale som fremmer argumentasjon, har blitt beskrevet nærmere i tilknytning til Trafford og Leshems teori som at eksaminator legger samtalen på et nivå som inviterer til argumentasjon. Funnene i undersøkelsen og tolkningen av dem kan diskuteres, og jeg vil gjøre det med henblikk på det som ovenfor er nevnt av andre mulige svar på spørsmålet om hva som fremmer argumentasjon i studentenes svar i muntlig eksamen.

Det første alternative svaret som ble lansert ovenfor i avsnittet "Argumentasjon og interaksjon i muntlig eksamen", var at en psykodynamisk interaksjon knyttet til bruk av muntlig språk kan få studenten til å ville påvirke og overbevise med bruk av argumentasjon som redskap. Undersøkelsen som er referert i denne artikkelen, gir ikke noe bidrag til å bekrefte eller avkrefte dette svaralternativet. Samtidig blir funnene i undersøkelsen og tolkningen av dem 
heller ikke svekket av tanken på at dette svaret også er mulig, fordi muntlig språk brukes både i samtaleavsnittene som blir innledet med nye spørsmål fra eksaminator og i samtaleavsnittene som blir innledet med henvisning til noe studenten har sagt. Og en eventuell argumentasjonsfremmende effekt av psykodynamikk i muntlig språk kan derfor antas å være til stede like mye eller like lite i den ene typen avsnitt som i den andre.

Det samme gjelder antatt effekt av frykt for hva som kan komme i muntlig eksamen, som blir fremhevet i det andre av de fire svaralternativene. Det gikk nærmere bestemt ut på at sosial interaksjon med risiko for å åpenbare svakhet direkte overfor andre, kan få studenten til å sikre seg på forhånd ved å forberede både svar på mulig spørsmål og argumenter til å forsvare dem ved behov. Økt forberedelse med vekt på ferdighet i argumentasjon vil åpenbart kunne fremme argumentasjon i studenters besvarelser i muntlig eksamen. Men når slik forberedelse er gjennomført og økt argumentasjonsevne er oppnådd, kan det fremme argumentasjon i studentenes svar både der eksaminator stiller nye spørsmål og der han henviser til noe studenten har uttalt for så å gå videre for eksempel med oppfordring til utdyping av svaret.

Det tredje svaralternativet ovenfor på spørsmålet om hva som fremmer argumentasjon, er en bestiller-leverer-interaksjon hvor studenten blir bedt om å argumentere. Svaralternativet er isolert sett lite interessant fordi det er helt åpenbart at krav om argumentasjon i spørsmålet kan fremme argumentasjon i svaret. For funnene i undersøkelsen og tolkningen av dem ovenfor er det likevel interessant dersom eksplisitt krav om argumentasjon kan knyttes bare til eller mest til ett av de to alternativene: avsnitt innledet med nye spørsmål og avsnitt innledet med henvisning til noe studenten har sagt. Men kontroll av dette i materialet viser at eksaminator ber direkte om begrunnelse i begge typer avsnitt og at det skjer i like mange avsnitt av begge typer, nærmere bestemt i to av hver. For avsnitt som innleder med at eksaminator henviser direkte til noe studenten har sagt, gjelder det altså for 2 av 46. Det betyr at eksplisitt krav om begrunnelse ikke er et særtrekk eller noe typisk for samtaler med gjensidig respons, med dialog-interaksjon mellom eksaminator og student. Det taler videre for at det en student i slike samtaler måtte oppleve av forventninger om å prestere mer og bedre i sine svar, er noe som for det meste kommer indirekte, eller som Trafford og Leshem uttrykker det, fra det høyere nivået i samtalen som eksaminators innspill legger opp til.

Enda en innvending som kan rettes mot funnene i den refererte undersøkelsen og tolkningen av dem, er at det er usikkert hvor vidt funnene gjelder muntlig eksamen som sådan, fordi et skriftlig arbeid utgjør et element i de åtte eksamenene. Det gjelder konkret en såkalt utviklingsoppgave på ca. 25 sider som tidigere var blitt vurdert. Denne oppgaven kunne studenten ta med til den muntlige eksamenen, og både studenten og eksaminator kunne henvise til dens innhold under den muntlige samtalen. Svært mange muntlige eksamener i høyere utdanning har slike skriftlige arbeider som et element. Og i registreringen 
ovenfor av 43 avsnitt hvor eksaminator henviser til noe studenten har uttalt, er det bare tatt med henvisninger til utsagn tidligere i den muntlige eksamenen. Siden det likevel er mulig å hevde at nærvær og bruk av et skriftlig arbeid gjør det usikkert hvordan funnene og tolkningen kan anføres som resultater av forskning på muntlig eksamen, ble det gjennomført enda en omgang med avgrensninger i materialet. Den bestod i å se bort fra alle avsnitt som på noen måte berører innholdet $\mathrm{i}$ den skriftlige besvarelsen. Før denne siste avgrensningen var det i materialet 2,7 ganger flere avsnitt med argumentasjon og innledning med henvisninger til noe studentene har sagt, mens det etter den var 3,2 ganger flere av samme type avsnitt. Den ekstra undersøkelsen av materialet som ikke på noen måte berører innholdet i den skriftlige besvarelsen, skaper derfor ikke større usikkerhet om resultatet. Den styrker i stedet bekreftelsen av tesen om at samtale i muntlig eksamen hvor både student og eksaminator responderer på hverandres utsagn, bidrar til å fremme argumentasjon i studentens svar.

Konklusjon

Artikkelen har presentert hvordan evne til argumentasjon blir tillagt stor betydning i læreryrket og følgelig også i lærerutdanning, og den har beskrevet hvordan argumentasjon blir rangert som prestasjon på høyt nivå i teori om vurdering i høyere utdanning. Artikkelen har videre reist spørsmål om hva som kan fremme argumentasjon i eksamensbesvarelser, og fremsatt fire mulige svar ut fra tidligere forskning på vurdering i høyere utdanning. En faktor har blitt nærmere undersøkt: eksaminators gjennomføring av eksamen. To fremgangsmåter har blitt satt opp mot hverandre: å stille stadig nye spørsmål og å bryte rekken av nye spørsmål ved å henvise til og følge opp studentens utsagn underveis i eksamen. Registrering av argumentasjon i studentenes svar etter disse to mulighetene ga langt flere funn av argumentasjon etter den siste, fra 2,7 til 3,2 ganger mer. Dette tolkes som klar indikasjon på at overganger fra stadig nye spørsmål til samtaler med gjensidig respons, som i referert teori kalles dialog-interaksjon, fremmer argumentasjon i studentens svar. I eksaminators henvisninger til og oppfølginger av studentens utsagn er det i materialet funnet lite direkte oppfordring til argumentasjon. Det er i stedet for det meste funnet små, åpne signaler om at eksaminator har hørt studentens svar og tenkt at det er mulig å si noe mer og bedre. Slike signaler kan tolkes som uttrykk for at eksaminator legger samtalen med studenten på et nivå som indirekte inviterer til argumentasjon.

Etter utspørring av og samtale med studenten følger en samtale mellom eksaminator og sensor, som i denne artikkelen er blitt omtalt med fellesbetegnelsen eksaminator. Det er en samtale som vurderer studentens prestasjon, og det er ikke sjelden slike samtaler legger vekt på mengden av 
refleksjon og argumentasjon i studentens svar. Det bør forskes mer på muntlig eksamen for å avklare nærmere om eksaminators gjennomføring av eksamen bidrar til å bestemme mengden av argumentasjon i studentens svar. Videre forskning på argumentasjon og interaksjon i muntlig eksamen kan også nyansere innholdet i studentenes argumentasjon og undersøke mer enn forekomsten av begrunnelser for påstander. For eksempel kan argumentasjoner både for og imot en sak tas med i vurderingen. Flere former for muntlig eksamen kan også undersøkes, for eksempel muntlig eksamen hvor lærerstudentene blir prøvd som gruppe og gis mulighet til å diskutere spørsmålene som blir stilt. Den siste formen kan ifølge Joughins undersøkelse gi mer rom for både for- og motargumenter (Joughin, 2008: 61).

\section{Litteratur}

Biggs, J. B. og Collis, K. F. (1982). Evaluating the quality of learning: the SOLO taxonomy (Structure of the observed learning outcome). New York: Academic Press

Biggs, J. B. (1992). A qualitative approach to grading students, HERDSA News,14 (3), 3-6.

Biggs, J. B. (2001). Assessing for Quality in Learning. I L. Suskie (Red.), Assessment to Promote Deep Learning. Insight from AAHE’s 2000 and 1999 Assessment Conferences. (65-68). Washington: American Association for Higher Education

Biggs, J. B. og Tang, C. (2007). Teaching for quality learning at university: What the student does.Berkshire: Society for Research into Higher Education \& Open University Press

Dobson, S. (2007). Teoretisering rundt muntlig eksamen - en kvalitativ tilnærming. Norsk Pedagogisk Tidsskrift 91(2), 137-149

Dobson, S. (2009). Muntlig vurdering - utfordring og muligheter. I Dobson, S., Eggen, A. B og Smith, K. (red.) Vurdering, prinsipper og praksis. (190-200) Oslo: Gyldendal Akademisk

Hattie, J. A. C. og Brown, G. T. L. (2004). Cognitive Processes in assessment tools for teaching and learning: The SOLO Taxonomy. asTTLE Technical Report \#43. Auckland: University of Auckland, Ministry of Education

HiØ. (2007). Studieplan uten emnebeskrivelse. Praktisk-pedagogisk utdanning, heltid.

Lastet ned 07.11, 2013, fra:

http://www.hiof.no/nor/hogskolen-i-ostfold/forstudenter/studieplaner/studieplaner?lang=nor\&displayitem=200\&module=studieinfo\&typ $\mathrm{e}=$ studieue\&subtype $=1$

HiØ. (2008). Informasjon til studenter, sensorer og veiledere. Om eksamen på PPU ved HiØ: Vurdering og fastsetting av eksamenskarakterer. Halden: Høgskolen i Østfold

Joughin, G. (2008). Oral assessment from the learners perspective. The experience of oral examination in post-compulsory education. Saarbrücken: VDM Verlag Dr. Müller

Joughin, G. (2009). Orality and learning in oral presentations. Paper presentert på den 35. årlige konferansen for International association for educational assessment (IAEA), Brisbane. Lastet ned 07.11, 2013, fra: http://www.iaea.info/documents/paper_4d540a4.pdf 
Joughin, G. (2010). A short guide to oral assessment. Leeds: Leeds metropolitan university. Lastet ned 07.11, 2013, fra:

https://www.leedsmet.ac.uk/publications/files/100317_36668_ShortGuideOralAssess1_W EB.pdf

Joughin, G. (2011). ”Speaking of which ...”: The intriguing case of the spoken word in assessment. HERDSA News 32(03), 1 og 3-4.

Jørgensen, C. og Onsberg, M. (2008). Praktisk argumentation. København: Nyt teknisk forlag

Kehm, B. M. (2001). Oral examination in German universities. Assessment in Education, 8(1), 25-31.

Miller, N. (2002). Alternative Forms of Formative and Summative Assessment.Bristol: University of Bristol. The Economics Network

Ong, W. (1982). Orality and literacy: The technologizing of the world. London: Routledge

Pearce, G., Lee, G. (2009). Viva Voce (Oral Examination) as an assessment Method: Insights From Marketing Students. Journal of Marketing Education 31(2), 120-130.

Ramsden, P. (2003). Learning to teach in higher education. London: Routledge

Remer, R. (1990). Improving oral exams - an application of Morenean sociometry. Journal of group Psychotherapy Psychodrama \& and Sociometry, 43(1), 35-42.

Sjøberg, S. (2006). Naturfag i skole og samfunn: En tverrfaglig historie. I S. Ongstad (Red.), Fag og didaktikk i lærerutdanning. Kunnskap i grenseland.(61-84). Oslo: Universitetsforlaget

Toulmin, S. (1958). The uses of argument. Cambridge: CambridgeUniversity Press

Trafford, V. N. (2003). Questions in doctoral vivas: views from the inside. Quality assurance in education 11(2), 114-122

Trafford, V. N. og Leshem, S. (2002a). Anatomy of a doctoral Viva. Journal of Graduate Education 3(2), 33-41. Nettutgave paginert side 1-12:

Lastet ned 07.11, 2013, fra: http://www.academia.edu/1054240/Anatomy_of_a_Doctoral_Viva

Trafford, V. N. og Leshem, S. (2002b). Starting at the end to undertake doctoral research: predictable questions as stepping stones. Higher Education Review 35(1), 31-49.

UFD.(2003). Rammeplan for Praktisk-pedagogisk utdanning, 2003. Lastet ned 07.11, 2013, fra:

http://www.regjeringen.no/upload/KD/Vedlegg/UH/Rammeplaner/L\%C3\%A6rer/2Ramm eplan_2003_PPU.pdf 